\title{
Effects of microwave irradiation by means of a horn antenna in the process of seed extraction on Scots pine (Pinus sylvestris L.) cone moisture content and seed germination energy and capacity
}

\author{
Monika Aniszewska ${ }^{1} \cdot$ Krzysztof Słowiński $^{2}$
}

Received: 10 December 2015/Revised: 15 April 2016/Accepted: 30 April 2016/Published online: 16 June 2016

(c) The Author(s) 2016. This article is published with open access at Springerlink.com

\begin{abstract}
The paper presents the results of experiments involving the exposure of Scots pine (Pinus sylvestris L.) cones to microwave radiation. The pine cones were obtained from the Maskulińskie and Brzesko Forest Districts (both in Poland). Pine cone length, thickness, and weight were determined and found to be significantly different between the two locations. Pine cones were exposed to $2.45-\mathrm{GHz}$ microwaves emitted by a horn antenna, which was either fixed or moving at a speed of $0.002 \mathrm{~m} \mathrm{~s}^{-1}$ over the cones. Total microwave emission time ranged from 30 to $441 \mathrm{~s}$, depending on the test variant. The measured parameters included changes in pine cone moisture content as well as the germination capacity and viability class of the extracted seeds. It was found that pine cone moisture content decreased on average by 0.3 to $6 \%$, depending on the amount of microwave radiation applied. It was found that pine cone size, the amount of microwave radiation, and the distance between the cones and the horn antenna affected seed germination and viability class. In most experimental variants, the seeds were damaged by microwaves. Viable seeds (classes I and II) were obtained after $30 \mathrm{~s}$ of exposure to microwave radiation from a fixed horn antenna positioned at a distance of $0.04 \mathrm{~m}$ over the cones. The application of a moving antenna positioned $0.14 \mathrm{~m}$
\end{abstract}

Communicated by Dr. Rainer Matyssek.

Monika Aniszewska

monika_aniszewska@sggw.pl

1 Department of Agricultural and Forest Machinery, Warsaw University of Life Sciences - SGGW, Warsaw, Poland

2 Institute of Forest Utilization and Forest Technology, University of Agriculture in Cracow, Cracow, Poland over the cones resulted in seeds of viability classes II and III following a single microwave sweep over the seeds.

Keywords Seed extraction - Microwaves - Seed viability class $\cdot$ Scale opening

\section{Introduction}

The seeds of coniferous trees, including Scots pine (Pinus sylvestris L.), Norway spruce (Picea abies L.), European larch (Larix decidua Mill.), and silver fir (Abies alba Mill.), are borne in cones. Thus, the collection of seeds involves their extraction from cones in a long and laborious process. Therefore, new and improved techniques of seed extraction are sought. Efforts have been made to shorten the extraction process by increased drying temperature (Antosiewicz 1979), lowering pressure (Bogdanow 1966), mechanical cone trimming (cutting off the base), sorting cones into different size categories, and water humidification during stepwise drying (Aniszewska 2004, 2007, 2012). However, despite the undertaken research efforts, extraction time has not been significantly reduced and effective ways of seed extraction have not been developed. One of the reasons is the high susceptibility of the seeds to external factors, which may readily damage them.

The present paper proposes the use of microwave radiation in a preliminary step of seed extraction to reduce the initial moisture content of the cones.

Microwaves are invisible to the human eye. Their electromagnetic spectrum is in the range of radio frequencies and infrared radiation. Out of the wide microwave spectrum, only selected frequencies are allocated to industrial, scientific, and medical uses (in the presented experiments, $2.45 \mathrm{GHz}$ was used). Microwaves are 
reflected by metal and pass through electrically neutral materials such as glass, most plastics, ceramic items, and paper. If absorbed, they generate heat in the absorbing material. Two particularly important properties of microwaves include volumetric heating and reverse temperature gradients in the heated material (Jakubowski 2010; Pietruszewski and Kania 2011; Słowiński 2013).Today, the use of microwaves is widespread in many applications, for instance in medicine (Thuery 1992), in agriculture and forestry (Krug 1990), for improved seed germination (Jakubowski 2008; Warchalewski et al. 2007; Adair 2003; Malkin and Panina 1996; Nelson 1985), for soil disinfection (Słowiński 2013; Velázquez-Martí et al. 2006), in the wood industry for wood modification and disinfestations (Krajewski 1990a, b, 2001; Hong-Hai et al. 2005), and for drying of agricultural products (Al-Harahsheh et al. 2009; Contreras et al. 2008; Dadali et al. 2007; Funebo and Ohlsson 1998; Khraisheh et al. 2004; Soysal 2004; Vadivambal and Jayas 2007; Zhang et al. 2006; Pinkrova et al. 2003; Maskan 2001; Backer and Walz 1985; Brusewitz 1984).

Prior to placing cones in a convective dryer, we propose that they could be briefly exposed to strong microwaves. This preliminary step will enable faster water elimination from closed cone scales and lead to quicker scale opening. The beginning of scale opening is defined as the separation of scales from one another without visible flexing back.

The first research question is whether microwaves can be applied in the process of Scots pine seed extraction to accelerate the initial opening of scales. The other question is whether microwave radiation adversely affects the germination energy and capacity of the collected seeds. The objective was to determine the most beneficial conditions of microwave use in the process of seed extraction.

\section{Materials and methods}

The material consisted of Scots pine (Pinus sylvestris L.) cones obtained from two extraction facilities: one in the Maskulińskie Forest District, State Forest Regional Directorate in Białystok (Ruciane-Nida), and one in the Brzesko Forest District, State Forest Regional Directorate in Cracow. The cones originated from commercial seed stands and were collected in December and January, in the seed extraction season 2014/2015. Closed Scots pine cones were delivered to the laboratory of the Institute of Forest Utilization and Forest Technology, University of Agriculture in Cracow.

One hundred cones from both locations were measured in terms of length and thickness using an electronic caliper with an accuracy of $0.01 \mathrm{~mm}$, and weighed by means of an
Axis 2100 scale with an accuracy of 0.01 g. Furthermore, the form (Białobok et al. 1993) and shape (Pravdin 1964) of the studied cones were determined.

Cones from both locations were divided into two lots. The first one was further subdivided into 18 batches weighing approximately $600 \mathrm{~g}$ each, and the other one was subdivided into 24 batches weighing approximately $200 \mathrm{~g}$ each. The batches were placed on metal trays with dimensions of $430 \mathrm{~mm} \times 140 \mathrm{~mm}$ in a single layer so that they would cover the entire tray (larger batches) or a part thereof (smaller batches; Fig. 1). Subsequently, the trays with cones were weighed on a laboratory scale.

Subsequently, trays with cones from the first lot were placed under a microwave emitter (horn antenna), one at a time. The antenna was moved over the tray with cones at a constant speed of $0.002 \mathrm{~m} \mathrm{~s}^{-1}$. In the first experiment, the antenna was positioned at a distance of $0.04 \mathrm{~m}$ over the tray, and in the second experiment at a distance of $0.14 \mathrm{~m}$. Figure 2 shows a schematic of the experimental stand.

The microwave antenna was moved once (in a single sweep) over 8 cone batches from the Maskulińskie Forest District and 6 batches from the Brzesko Forest District; it was moved twice (double sweep) over 4 cone batches from both locations. In all cases, the cone batches were derived from the first lot of cones.

Cones from the second lot were also placed under the microwave antenna, but in this case the electromagnetic device was fixed at a distance of $0.04 \mathrm{~m}$ over the tray. In this test, the microwave exposure time was 30,60 , and $120 \mathrm{~s}$ for cones from the Maskulińskie Forest District, and additionally 90 and $150 \mathrm{~s}$ for cones from the other Forest District. Each test variant was done in triplicate.

The power output of the $2.45-\mathrm{GHz}$ microwave emitter was $800 \mathrm{~W}$. The aperture area of the horn antenna was $0.024254 \mathrm{~m}^{2}(0.181 \mathrm{~m} \times 0.134 \mathrm{~m})$, and the mean microwave power density was $33 \mathrm{~kW} \mathrm{~m}^{-2}$. The intensity distribution of the electromagnetic field emitted by the horn antenna was visualized using CADFEKO ver. 2.0 .5 software (http://www.feko.info; Fig. 3).

Immediately following exposure to microwave radiation, the trays with cones were weighed on a laboratory scale to measure mass and moisture loss.

During the experiments at the Institute of Forest Utilization and Forest Technology in Cracow, air humidity and temperature in the laboratory were recorded using a Volt craft ST8820 multimeter with an accuracy of $0.1 \%$ and $0.1^{\circ} \mathrm{C}$, respectively.

Following microwave irradiation, the cones were allowed to stand until opening in a storage area of the Department of Agricultural and Forest Machinery, Warsaw University of Life Sciences, in which air humidity and temperature were monitored using a Hygro Palm sensor with an accuracy of $0.1 \%$ and $0.1{ }^{\circ} \mathrm{C}$, respectively. 
(a)

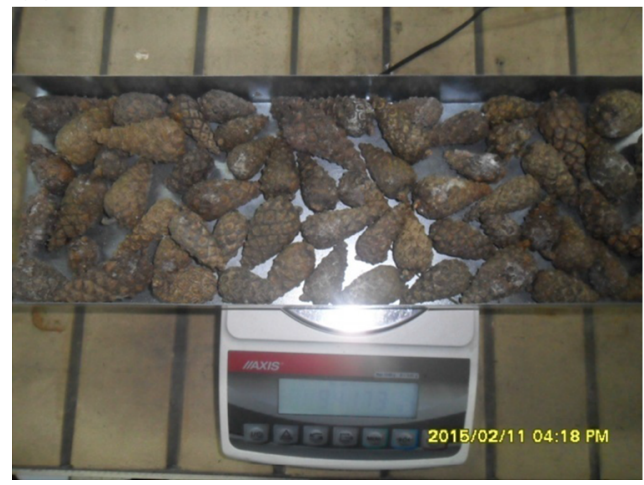

(b)

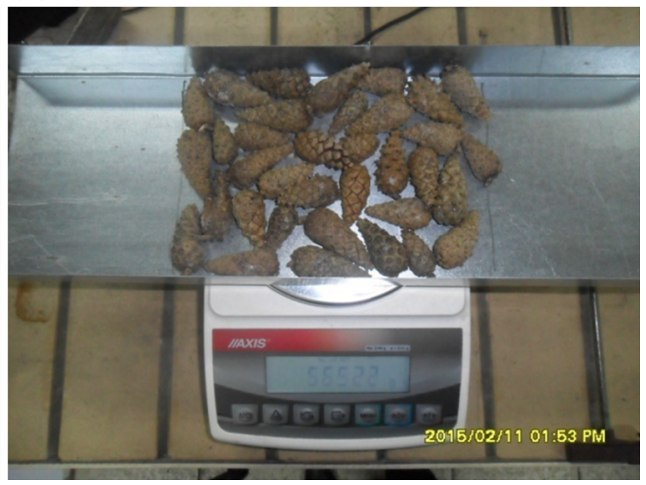

Fig. 1 Tray with cones: $\mathbf{a}-$ batch from the first lot, $\mathbf{b}$ - batch from the second lot

Fig. 2 Microwave device fitted on a guide: 1 stepper motor, 2 belt driver, 3 split nut, 4 horn antenna, 5 tray with cones, 6 lead screw, 7 guide, 8 adjustable stand, 9 stepper motor control system (Słowiński 2013)

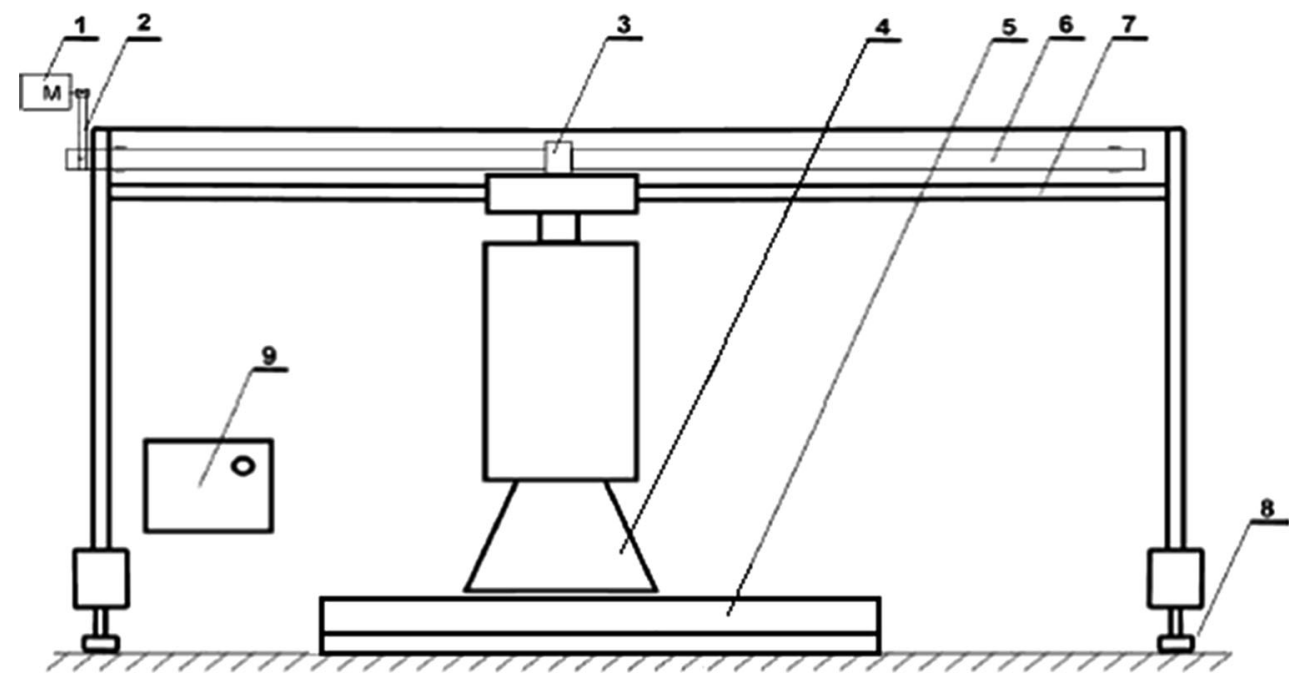

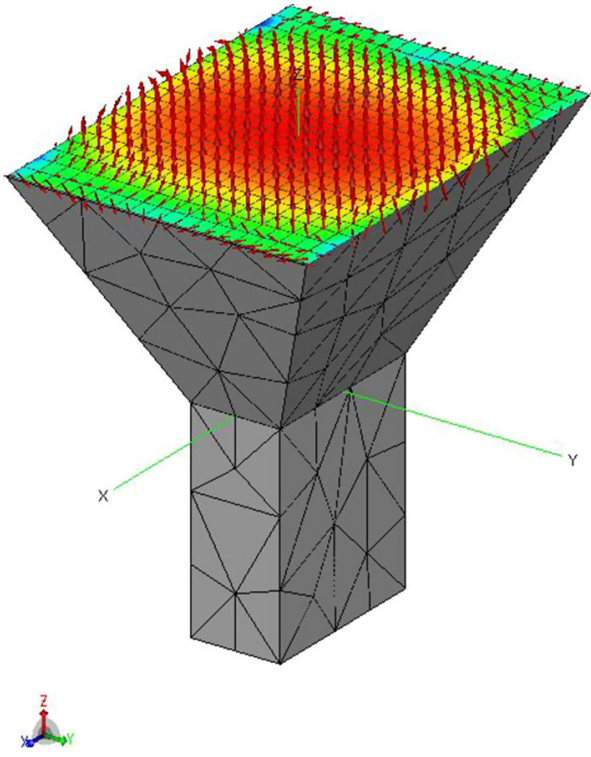

Fig. 3 Intensity distribution of the electromagnetic field emitted from the designed horn antenna, red max, green min (Słowiński 2013)
After 3 weeks, seeds were extracted manually from the opened cones, dewinged, and cleaned by winnowing. Subsequently, germination energy and capacity, as well as seed viability, were determined pursuant to the standards BN-76/9211-02 (1976) (Załęski 1995) and PN-R-65700 (1998). According to the definition, germination energy reflects the rate at which this process occurs and is given as the proportion of seeds which germinate half-way into the expected germination period. High germination energy indicates good seed viability and a high commercial value of the seeds. On the other hand, germination capacity is the proportion of planted seeds which form normal sprouts at the maximum time needed for all viable seeds to germinate (Załęski 1995).

Seed viability (quality) classes were determined based on germination energy and capacity. According to Załęski (1995), in the case of Scots pine seeds, viability class I is defined as germination energy of over $85 \%$ and germination capacity of over $91 \%$; the corresponding values for viability class II are 70 and $81 \%$, and for viability class III, these are 50 and $70 \%$. 
Seeds from the various batches were placed in a Jacobsen germinator at the laboratory of the Department of Agricultural and Forest Machinery, Warsaw University of Life Sciences, to determine germination energy and capacity. The seeds were placed on filter paper discs in three replicates $(3 \times 100)$ and covered with plastic domes. Throughout the trial, a constant substrate temperature of $24 \pm 1{ }^{\circ} \mathrm{C}$ was maintained in the germinator, and the seeds were artificially lit for $8 \mathrm{~h}$ a day.

For every seed batch, germination energy and capacity were calculated as an arithmetic mean from 300 seeds On days $7,10,14$, and 21 , properly germinated seeds (with sprout length equal to at least half the seed length) were picked from the filter paper in the Jacobsen germinator. Germination energy was determined on day 7 and germination capacity on day 21 . Seeds which did not germinate on day 21 were crushed to check for empty seeds.

In order to calculate loss of weight, as well as moisture content before and after microwave irradiation of cones, following seed extraction all batches were dried in a Heraus UT 6120 laboratory dryer at $105 \pm 1{ }^{\circ} \mathrm{C}$ for $24 \mathrm{~h}$ to dry weight. Changes in cone weight and moisture content were computed using the formulas given by Kubiak and Laurow (1994).

The germination energy and capacity of microwave irradiated cones were compared to controls which had not been exposed to microwave radiation. Experiments were conducted using a Jacobsen germinator.

Statistical analysis was carried out by means of Statistica 10 (2011) software using basic statistics and analysis of variance (ANOVA). Experiments on the first lot of pine cones were subjected to factor analysis, with the factors being tray-to-antenna distance and cone origin. Analysis for the other lot of pine cones included microwave exposure time and cone origin. Statistical analysis included pine cone weight and moisture loss as well as the germination energy and capacity of seeds following microwave irradiation.

\section{Results}

\section{Basic parameters of the studied cones}

Pine cones from the Maskulińskie Forest District were on average $44.76 \mathrm{~mm}$ long, $21.93 \mathrm{~mm}$ thick, and weighed $8.25 \mathrm{~g}$, while those from the Brzesko Forest District were on average $41.08 \mathrm{~mm}$ long, $18.67 \mathrm{~mm}$ thick, and weighed $6.04 \mathrm{~g}$. The basic statistics, including mean, minimum, maximum, standard deviation, coefficient of variability, and standard error values for the examined pine cone parameters, were computed using Statistica 10 software and are given in Table 1.

As can be seen from the table, the pine cones from the Maskulińskie Forest District are larger both in terms of external dimensions and weight than those from the Brzesko Forest District. According to Białobok et al. (1993), the length of Scots pine cones ranges from 19 to $70 \mathrm{~mm}$, with the thickness being from 12 to $32 \mathrm{~mm}$. Pine cones of both origins fall within those limits, as shown by the minimum and maximum values given in Table 1 .

The statistical parameters for the length, thickness, and weight of pine cones show that those from the Maskulińskie Forest District are characterized by a higher standard deviation and error than those from the other location. Statistical analysis of cone length and thickness indicates low variability, while of cone weight indicates average variability (coefficient of variability).

The studied pine cone parameters were found to have a normal distribution. Analysis of variance with Duncan's multiple comparisons (Statistica 10) shows that pine cones of the two origins differ significantly between each other. Analysis of variance returned the following values: $F_{(1,98)}=14.82 ; p=0.0002$ for length, $F_{(1,98)}=49.80$; $p<0.0001$ for thickness, and $F_{(1,98)}=25.56 ; p<0.0001$ for weight. The two dimensions of pine cones were found to be significantly correlated: An increase in pine cone thickness by $1 \mathrm{~mm}$ caused an average increase in length by

Table 1 Basic statistics of pine cones from the Maskulińskie and Brzesko Forest Districts (Statistica 10)

\begin{tabular}{|c|c|c|c|c|c|c|}
\hline Parameter & Mean & Minimum & Maximum & SD & Coefficient of variation & SE \\
\hline \multicolumn{7}{|c|}{ Maskulińskie Forest District } \\
\hline Length (mm) & 44.76 & 34.80 & 56.20 & 4.839 & 10.81 & 0.68 \\
\hline Thickness (mm) & 21.93 & 16.10 & 28.90 & 2.489 & 11.35 & 0.35 \\
\hline Weight (g) & 8.25 & 3.90 & 14.90 & 2.447 & 29.66 & 0.35 \\
\hline \multicolumn{7}{|c|}{ Brzesko Forest District } \\
\hline Length (mm) & 41.08 & 32.40 & 55.00 & 4.725 & 11.50 & 0.67 \\
\hline Thickness (mm) & 18.67 & 14.20 & 25.00 & 2.121 & 11.36 & 0.30 \\
\hline Weight (g) & 6.04 & 3.12 & 11.24 & 1.890 & 31.29 & 0.27 \\
\hline
\end{tabular}


$1.46 \mathrm{~mm}$ in the Maskulińskie cones and by $1.97 \mathrm{~mm}$ in the Brzesko cones (Fig. 4). According to Staszkiewicz (1968), the average length-to-thickness ratio for pine cones from Poland amounts to 1.7 .

Given the pine cone length-to-thickness ratio, cones of both origins exhibited a shape classified by Pravdin (1964) as long and thick (h/d of 2.0 to 2.5 ). As many as $80 \%$ of pine cones from the Maskulińskie Forest District were characterized by the plana-gibba form, while $90 \%$ of cones from the other location were of the plana form.

\section{Changes in the weight and moisture content of pine cones exposed to microwave radiation}

\section{Moving horn antenna}

Pine cones of both origins exposed to microwaves from a moving horn antenna positioned $0.04 \mathrm{~m}$ over the tray lost an average of $5.70 \mathrm{~g}$ after one antenna sweep, which corresponds to almost $1 \%$ of their initial weight (Table 2).

After a double sweep, the weight of pine cones from the Maskulińskie Forest District decreased by $19.89 \mathrm{~g}$ $(3.31 \%)$, while that of cones from the Brzesko Forest District by $17.66 \mathrm{~g}(2.95 \%)$. The much larger weight loss after the double sweep may be attributable to the fact that pine cones continued to intensively lose moisture for some time after the radiation had stopped.

An increase in the tray-to-antenna distance from 0.04 to $0.14 \mathrm{~m}$ reduced the loss of weight and moisture content in the studied pine cones both in trials with single and double antenna sweeps. After one microwave sweep, the weight of pine cones from the Maskulińskie Forest District declined on average by $3.14 \mathrm{~g}(0.52 \%)$, and that of pine cones from the Brzesko Forest District decreased by $2.7 \mathrm{~g}(0.45 \%)$. In turn, a double sweep reduced the weight of pine cones from the former location by $8.87 \mathrm{~g}$

Fig. 4 Pine cone length-tothickness ratio for cones from the Maskulińskie and Brzesko Forest Districts

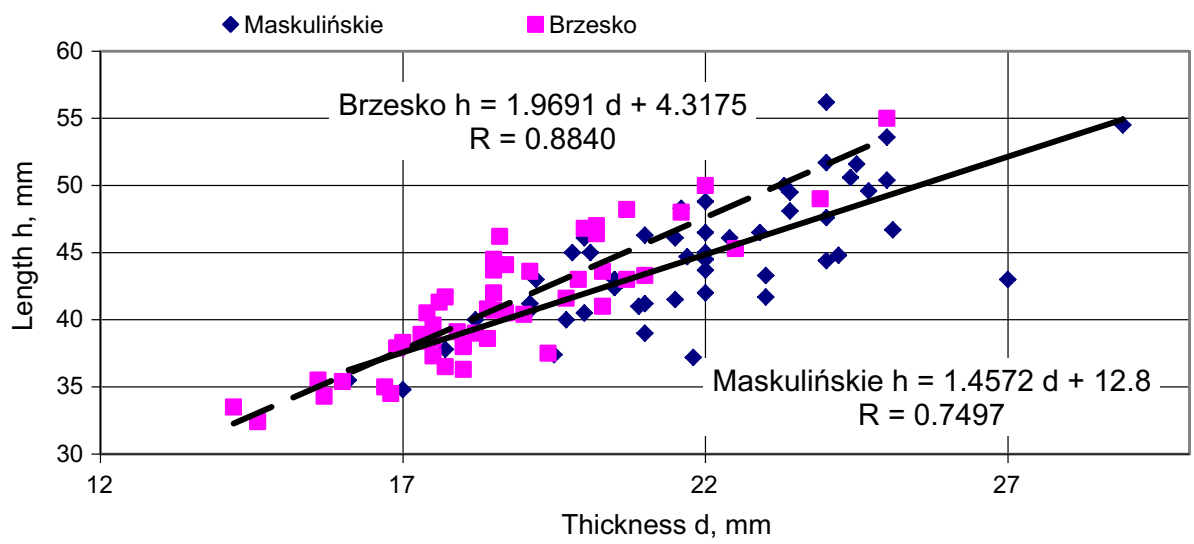

Table 2 Mean weight and moisture content of the various batches of Scots pine cones for a moving antenna positioned 0.04 and $0.14 \mathrm{~m}$ over the tray

\begin{tabular}{|c|c|c|c|c|c|c|c|c|}
\hline \multirow[t]{2}{*}{ Forest district } & \multirow[t]{2}{*}{$\begin{array}{l}\text { Antenna sweep } \\
\text { time (s) }\end{array}$} & \multicolumn{2}{|c|}{ Weight of cones } & \multicolumn{2}{|c|}{$\begin{array}{l}\text { Mean } \\
\text { weight loss }\end{array}$} & \multirow[t]{2}{*}{$\begin{array}{l}\text { Dry weight } \\
\text { (g) }\end{array}$} & \multicolumn{2}{|c|}{ Moisture content of cones } \\
\hline & & $\begin{array}{l}\text { Before } \\
\text { irradiation }(\mathrm{g})\end{array}$ & $\begin{array}{l}\text { After } \\
\text { irradiation }(\mathrm{g})\end{array}$ & $\mathrm{g}$ & $\%$ & & $\begin{array}{l}\text { Before } \\
\text { irradiation }(\%)\end{array}$ & $\begin{array}{l}\text { After } \\
\text { irradiation (\%) }\end{array}$ \\
\hline \multicolumn{9}{|l|}{$0.04 \mathrm{~m}$} \\
\hline \multirow{2}{*}{$\begin{array}{l}\text { Maskulińskie Forest } \\
\text { District }\end{array}$} & 223 & 576.58 & 570.88 & 5.70 & 0.99 & 428.65 & 34.51 & 33.18 \\
\hline & 442 & 601.60 & 581.71 & 19.89 & 3.31 & 442.20 & 36.05 & 31.55 \\
\hline \multirow{2}{*}{$\begin{array}{l}\text { Brzesko Forest } \\
\text { District }\end{array}$} & 220 & 590.98 & 585.27 & 5.70 & 0.97 & 440.23 & 34.24 & 32.94 \\
\hline & 440 & 599.25 & 581.59 & 17.66 & 2.95 & 444.30 & 34.88 & 30.90 \\
\hline \multicolumn{9}{|l|}{$0.14 \mathrm{~m}$} \\
\hline \multirow{2}{*}{$\begin{array}{l}\text { Maskulińskie Forest } \\
\text { District }\end{array}$} & 221 & 599.11 & 595.97 & 3.14 & 0.53 & 449.58 & 33.26 & 32.57 \\
\hline & 442 & 593.05 & 584.18 & 8.87 & 1.50 & 443.80 & 33.63 & 31.63 \\
\hline \multirow{2}{*}{$\begin{array}{l}\text { Brzesko Forest } \\
\text { District }\end{array}$} & 220 & 595.88 & 593.19 & 2.70 & 0.45 & 441.47 & 34.98 & 34.36 \\
\hline & 441 & 600.41 & 592.64 & 7.77 & 1.29 & 445.30 & 34.83 & 33.09 \\
\hline
\end{tabular}


$(1.5 \%)$ and that of cones from the latter location by $7.77 \mathrm{~g}(1.29 \%)$

The mean initial moisture content of pine cones from the Maskulińskie Forest District was 34.08\%, and that of the Brzesko pine cones was $34.67 \%$. The results for pine cones irradiated from a distance of $0.04 \mathrm{~m}$ show that their mean moisture content declined to $33 \%$ after a single microwave sweep and to $31 \%$ after a double sweep.

In the case of the tray-to-antenna distance of $0.14 \mathrm{~m}$, the moisture content of the studied pine cones decreased only by $0.5 \%$ relative to the initial value after a single microwave sweep and by $1.5 \%$ after a double sweep (Table 2).

Statistical analysis (ANOVA) showed the absence of significant correlations between loss of weight and pine cone origin for a single microwave sweep at a tray-toantenna distance of $0.04 \mathrm{~m}$. The only significant differences between pine cones of different origins were found for loss of weight at a tray-to-antenna distance of $0.14 \mathrm{~m}$ $\left(F_{(1,5)}=7.68 ; p=0.0393\right)$.

In addition, ANOVA indicated the absence of any significant correlations in the moisture content of pine cones between and after irradiation for the two pine cone origins at tray-to-antenna distances of 0.04 and $0.14 \mathrm{~m}$ for a single microwave sweep.

\section{Fixed microwave antenna}

The weight of pine cones exposed to microwaves emitted by a fixed horn antenna decreased with increased irradiation time. For instance, pine cones from the Maskulińskie Forest District, with an initial weight of approximately $215 \mathrm{~g}$, lost on average $0.61 \mathrm{~g}(0.28 \%)$ following an exposure of $30 \mathrm{~s}$. An irradiation time of $60 \mathrm{~s}$ led to an average weight loss of $2.22 \mathrm{~g}$ ( $1.03 \%$ of initial weight). Finally, pine cones exposed to microwaves for $120 \mathrm{~s}$ lost approximately $10 \mathrm{~g}$, or $4.66 \%$ of their initial weight.

In the case of pine cones from the Brzesko Forest District, their weight decreased by $0.25 \%$ after $30 \mathrm{~s}$ of microwave irradiation, by $0.98 \%$ after $60 \mathrm{~s}$, by $2.3 \%$ after $90 \mathrm{~s}$, by $3.54 \%$ after $120 \mathrm{~s}$, and by $4.94 \%$ after $150 \mathrm{~s}$.

Differences in lost weight between pine cones of the two origins amounted to $0.03 \%$ after $30 \mathrm{~s}, 0.05 \%$ after $60 \mathrm{~s}$, and $1.12 \%$ after $120 \mathrm{~s}$ (Table 3 ).

Results for both pine origins after microwave exposure times of 30,60 , and $120 \mathrm{~s}$ were subjected to statistical analysis. ANOVA did not reveal a significant relationship between loss of weight and pine cone origin for exposure times of 30 and $60 \mathrm{~s}$, but did indicate significant differences for $120 \mathrm{~s}\left(F_{(1,4)}=36.92, p=0.0037\right.$ and $\left.F_{(1,4)}=47.69, p=0.0023\right)$.

ANOVA did not identify significant differences in moisture content before and after microwave irradiation for 30,60 , and $120 \mathrm{~s}$ between pine cones of different origins.

\section{Germination energy and capacity of seeds obtained from pine cones exposed to microwaves}

Table 4 gives the number of seeds germinated on days 7 , 10, 14, and 21. The antenna sweep time (the time it took the antenna to move over the tray filled with pine cones) was on average $221 \mathrm{~s}$ ( $3 \mathrm{~min} 41 \mathrm{~s}$ ). The seeds obtained from pine cones irradiated from a distance of $0.04 \mathrm{~m}$ germinated very poorly (9 to 31 per 100 seeds) and fell short of the lowest viability class (Załęski 1995).

The results for the germination energy and capacity of seeds obtained from pine cones irradiated from a distance of $0.14 \mathrm{~m}$ showed a marked improvement in terms of the number of germinated seeds. Seeds obtained from the Brzesko pine cones reached viability class II, while those obtained from the Maskulińskie cones were classified as viability class III. The number of seeds germinated from the various pine cone batches ranged from 71 to 87 .

ANOVA revealed significant correlations between germination energy $\left(F_{(1,19)}=18.09, p=0.0004, F_{(1,19)}=\right.$ $10.19, p=0.0048)$ and germination capacity $\left(F_{(1,19)}=\right.$ $\left.39.41, p<0.0001, F_{(1,19)}=27.47, p<0.0001\right)$ for seeds

Table 3 Mean weight and moisture content of the various batches of Scots pine cones for a fixed antenna positioned $0.04 \mathrm{~m}$ over the tray

\begin{tabular}{|c|c|c|c|c|c|c|c|c|}
\hline \multirow[t]{2}{*}{ Forest district } & \multirow[t]{2}{*}{ Microwave irradiation time (s) } & \multicolumn{2}{|c|}{ Cone weight } & \multicolumn{2}{|c|}{ Weight loss } & \multirow[t]{2}{*}{ Dry weight (g) } & \multicolumn{2}{|c|}{$\begin{array}{l}\text { Moisture content of } \\
\text { cones }\end{array}$} \\
\hline & & Before $(\mathrm{g})$ & After $(\mathrm{g})$ & g & $\%$ & & Before $(\%)$ & After $(\%)$ \\
\hline \multirow[t]{3}{*}{ Maskulińskie Forest District } & 30 & 217.31 & 216.70 & 0.61 & 0.28 & 162.25 & 33.94 & 33.57 \\
\hline & 60 & 215.23 & 213.02 & 2.22 & 1.03 & 161.80 & 33.02 & 31.66 \\
\hline & 120 & 214.95 & 204.94 & 10.01 & 4.66 & 161.41 & 33.17 & 26.97 \\
\hline \multirow[t]{5}{*}{ Brzesko Forest District } & 30 & 218.50 & 217.95 & 0.54 & 0.25 & 163.61 & 34.36 & 33.68 \\
\hline & 60 & 219.11 & 216.96 & 2.14 & 0.98 & 161.72 & 35.50 & 34.17 \\
\hline & 90 & 214.24 & 209.31 & 4.93 & 2.30 & 157.55 & 35.98 & 32.85 \\
\hline & 120 & 217.40 & 209.71 & 7.69 & 3.54 & 161.71 & 34.44 & 29.68 \\
\hline & 150 & 220.76 & 209.86 & 10.90 & 4.94 & 164.68 & 34.05 & 27.44 \\
\hline
\end{tabular}


Table 4 Germination energy and capacity, and viability class of seeds exposed to microwave radiation from a moving antenna positioned 0.04 and $0.14 \mathrm{~m}$ over the tray

\begin{tabular}{|c|c|c|c|c|c|c|c|}
\hline \multirow[t]{2}{*}{ Forest district } & \multirow{2}{*}{$\begin{array}{l}\text { Antenna sweep } \\
\text { time (s) }\end{array}$} & \multirow{2}{*}{$\begin{array}{l}\text { Germination energy } \\
\text { after } 7 \text { days }(\%)\end{array}$} & \multirow{2}{*}{$\begin{array}{l}\text { Viability } \\
\text { class }\end{array}$} & \multicolumn{2}{|c|}{ No. of seeds } & \multirow{2}{*}{$\begin{array}{l}\text { Germination capacity after } \\
21 \text { days }(\%)\end{array}$} & \multirow{2}{*}{$\begin{array}{l}\text { Viability } \\
\text { class }\end{array}$} \\
\hline & & & & $\begin{array}{l}\text { After } \\
10 \text { days }\end{array}$ & $\begin{array}{l}\text { After } \\
14 \text { days }\end{array}$ & & \\
\hline \multicolumn{8}{|c|}{ Antenna moving at $0.04 \mathrm{~m}$} \\
\hline \multirow{2}{*}{$\begin{array}{l}\text { Maskulińskie } \\
\text { Forest District }\end{array}$} & 223 & 14 & - & 17 & 17 & 18 & - \\
\hline & 442 & 2 & - & 3 & 3 & 3 & - \\
\hline \multirow{2}{*}{$\begin{array}{l}\text { Brzesko Forest } \\
\text { District }\end{array}$} & 220 & 28 & - & 38 & 40 & 40 & - \\
\hline & 440 & 3 & - & 4 & 4 & 4 & - \\
\hline \multicolumn{8}{|c|}{ Antenna moving at $0.14 \mathrm{~m}$} \\
\hline \multirow{2}{*}{$\begin{array}{l}\text { Maskulińskie } \\
\text { Forest District }\end{array}$} & 221 & 65 & III & 72 & 73 & 73 & III \\
\hline & 442 & 10 & - & 12 & 13 & 13 & - \\
\hline \multirow{2}{*}{$\begin{array}{l}\text { Brzesko Forest } \\
\text { District }\end{array}$} & 220 & 75 & II & 84 & 85 & 85 & II \\
\hline & 441 & 31 & - & 33 & 36 & 36 & - \\
\hline
\end{tabular}

from pine cones of both origins and for both antenna distances $(0.04$ and $0.14 \mathrm{~m})$ with one microwave sweep.

A double microwave antenna sweep over the tested pine cone batches with a view to lowering their initial moisture content did not lead to satisfactory results. A sweep time of over 7 min caused almost complete destruction of the seeds. No significant correlation (ANOVA) was found between germination energy and capacity for an antenna distance of $0.04 \mathrm{~m}$ during a double sweep. In contrast, a significant relationship between the studied viability parameters was found for an antenna positioned 0.14 mover the tray with cones $\left(F_{(1,4)}=78.45, p=0.0008\right.$ germination energy and $F_{(1,4)}=89.09, p=0.0007-$ germination capacity).

Table 5 gives the number of seed germinated on filter paper discs following exposure to microwaves emitted by a fixed antenna. An exposure of $30 \mathrm{~s}$ led to seeds with viability classes I and II. Under such irradiation conditions, the number of germinated seeds obtained from pine cones from the Brzesko Forest District ranged from 77 to 84 (with a mean of 81) while the corresponding number of germinated seeds from Maskulińskie cones ranged from 87 to 96 (with a mean of 91).

A longer exposure of pine cones to microwave radiation $(60,90,120$, and $150 \mathrm{~s})$ led to seeds of inferior quality.

ANOVA revealed statistically significant differences between germination energy and capacity and pine cone origin for pine cone exposure times of 30, 60, and $120 \mathrm{~s}$. Both origins (Maskulińskie and Brzesko) were included in statistical analysis. The results are as follows: germination energy for $30 \mathrm{~s}-F_{(1,16)}=14.34, p=0.0016$; for $60 \mathrm{~s}-$ $F_{(1,16)}=26.27, p=0.0001$; and for $120 \mathrm{~s}-F_{(1,9)}=$ 12.34, $p=0.0066$. Germination capacity for $30 \mathrm{~s}-$

Table 5 Germination energy and capacity, and viability classes of seeds obtained from pine cones exposed to microwave radiation from a fixed antenna positioned $0.04 \mathrm{~m}$ over the tray

\begin{tabular}{|c|c|c|c|c|c|c|c|}
\hline \multirow[t]{2}{*}{ Forest district } & \multirow{2}{*}{$\begin{array}{l}\text { Microwave } \\
\text { exposure time }\end{array}$} & \multirow{2}{*}{$\begin{array}{l}\text { Germination energy } \\
\text { after } 7 \text { days }(\%)\end{array}$} & \multirow{2}{*}{$\begin{array}{l}\text { Viability } \\
\text { class }\end{array}$} & \multicolumn{2}{|c|}{ No. of seeds } & \multirow{2}{*}{$\begin{array}{l}\text { Germination capacity after } \\
21 \text { days }(\%)\end{array}$} & \multirow{2}{*}{$\begin{array}{l}\text { Viability } \\
\text { class }\end{array}$} \\
\hline & & & & $\begin{array}{l}\text { After } \\
10 \text { days }\end{array}$ & $\begin{array}{l}\text { After } \\
14 \text { days }\end{array}$ & & \\
\hline \multirow{3}{*}{$\begin{array}{l}\text { Maskulińskie } \\
\text { Forest District }\end{array}$} & 30 & 86 & I & 89 & 91 & 91 & I \\
\hline & 60 & 24 & - & 27 & 27 & 28 & - \\
\hline & 120 & 6 & - & 7 & 8 & 8 & - \\
\hline \multirow{5}{*}{$\begin{array}{l}\text { Brzesko Forest } \\
\text { District }\end{array}$} & 30 & 77 & II & 81 & 81 & 81 & II \\
\hline & 60 & 43 & - & 47 & 49 & 49 & - \\
\hline & 90 & 17 & - & 18 & 19 & 19 & - \\
\hline & 120 & 10 & - & 12 & 12 & 12 & - \\
\hline & 150 & 1 & - & 1 & 1 & 2 & - \\
\hline
\end{tabular}


Table 6 Germination energy and capacity, and viability class of seeds extracted without microwave exposure

\begin{tabular}{|c|c|c|c|c|c|c|}
\hline \multirow[t]{2}{*}{ Forest District } & \multirow{2}{*}{$\begin{array}{l}\text { Germination energy after } \\
7 \text { days }(\%)\end{array}$} & \multirow{2}{*}{$\begin{array}{l}\text { Viability } \\
\text { class }\end{array}$} & \multicolumn{2}{|l|}{ No. of seeds } & \multirow{2}{*}{$\begin{array}{l}\text { Germination capacity after } \\
21 \text { days }(\%)\end{array}$} & \multirow{2}{*}{$\begin{array}{l}\text { Viability } \\
\text { class }\end{array}$} \\
\hline & & & After 10 days & $\begin{array}{l}\text { After } \\
14 \text { days }\end{array}$ & & \\
\hline $\begin{array}{l}\text { Maskulińskie Forest } \\
\text { District }\end{array}$ & 95 & I & 99 & 100 & 100 & I \\
\hline $\begin{array}{l}\text { Brzesko Forest } \\
\text { District }\end{array}$ & 94 & I & 98 & 99 & 99 & I \\
\hline
\end{tabular}

$F_{(1,16)}=19.16, p=0.0005$; for $60 \mathrm{~s}-F_{(1,16)}=40.56$, $p<0.0001$; and for $120 \mathrm{~s}-F_{(1,9)}=33.55, p=0.0003$.

Table 6 gives the number of germinated seeds obtained from pine cones of both origins which were not exposed to microwaves prior to extraction (control). Those seeds reached viability class $\mathrm{I}$.

\section{Discussion}

While it may be useful to apply microwave radiation in the process of seed extraction, further research is necessary to select a lower radiation power and frequency to improve power density parameters on the surface of pine cones. The applied power of $800 \mathrm{~W}$ emitted by a moving horn antenna and directed at pine cones positioned in a metal tray directly below it $(0.04 \mathrm{~m})$ resulted in damaging seeds of both origins. An increase in the distance between the pine cones and the antenna led to viable seeds of both origins, assigned to viability classes II (seeds from Brzesko pine cones) and III (seeds from Maskulińskie pine cones). Statistical analysis (ANOVA) of germination energy and capacity revealed significant differences between seeds obtained from pine cones of different origins.

A double sweep of the horn antenna over a tray filled with pine cones positioned 0.04 and $0.14 \mathrm{~m}$ under the antenna resulted in most seeds being damaged, as shown by viability investigations.

The seeds obtained from the second lot of pine cones, exposed to $60,90,120$, and 150 s of microwave radiation from a fixed antenna positioned $0.04 \mathrm{~m}$ over the cones, were also damaged, in contrast to pine cone batches exposed for the shortest amount of time (30 s). Germination energy and capacity results showed that in that case, the seeds met the specifications of viability classes I and II. Moreover, statistical analysis revealed significant differences depending on pine cone origin. It should be noted that pine cones from the Maskulińskie Forest District, which were classified as viability class I following $30 \mathrm{~s}$ of microwave irradiation, were characterized by a larger size (length and thickness) than those from the Brzesko Forest
District, which yielded seeds of viability class II. Therefore, it may be necessary to take into account the size of pine cones while setting the microwave parameters; this hypothesis requires verification in further research.

The results for the control samples confirmed that the seeds obtained from pine cones of both origins not exposed to microwave radiation were of viability class I.

Similar findings concerning the time of exposure of pine cones to microwaves were reported by Rukuni (1997), who compared seeds obtained by traditional extraction (with convective drying) to those extracted in a process with a step involving microwave irradiation. According to Rukuni, pine cones exposed to microwave radiation for $30 \mathrm{~s}$ yielded good-quality seeds.

The conducted tests show that while pine cones exhibited only a small weight loss following 30-s exposure to microwave radiation $(0.25-0.28 \%)$, most cone scales became separated from one another. Therefore, the application of microwaves may shorten the total time of seed extraction. However, this conclusion should be verified in further research encompassing the entire process of seed extraction (initial exposure to microwaves followed by convective drying in a cabinet).

It seems that the power of microwave radiation applied to pine cones should be reduced either by decreasing the power of the emitter (horn antenna) or by increasing the distance between the antenna and the pine cones (then, a given amount of radiation would affect a greater pine cone area). This would limit damage to the seeds. At the same time, the temperature of cones would increase more slowly, leading to a longer pine cone drying time at this stage and probably a greater loss of pine cone weight.

\section{Conclusions}

1. The exposure of the studied pine cones of two origins to microwave radiation in the first step of a seed extraction process reduced the initial pine cone moisture content of 33-36\% by $0.3-6 \%$, depending on the experimental variant and the initial separation of scales. 
2. The application of microwave radiation in the first step of seed extraction for $>30 \mathrm{~s}$, using either a moving or fixed horn antenna positioned at a distance of $0.04 \mathrm{~m}$ over closed pine cones, led to seed damage as shown by germination energy and capacity results. When the antenna was positioned $0.14 \mathrm{~m}$ over the tray with cones, seeds of viability classes II and III were obtained after a single microwave sweep.

3. Microwave radiation of $800 \mathrm{~W}$ applied for $30 \mathrm{~s}$ by means of a fixed horn antenna positioned $0.04 \mathrm{~m}$ over closed pine cones resulted in seeds of viability classes I and II. However, it seems that the time of exposure to microwaves could be shortened and the microwave power could be reduced to eliminate the risk of seed damage. This conclusion requires verification in further laboratory studies.

4. Microwave radiation was successfully applied in the initial step of a seed extraction process in order to reduce pine cone moisture content. However, irradiation time should not exceed $30 \mathrm{~s}$.

Open Access This article is distributed under the terms of the Creative Commons Attribution 4.0 International License (http://creativecommons.org/licenses/by/4.0/), which permits unrestricted use, distribution, and reproduction in any medium, provided you give appropriate credit to the original author(s) and the source, provide a link to the Creative Commons license, and indicate if changes were made.

\section{References}

Adair RK (2003) Biophysical limits on athermal effects of RF and microwave radiation. Bioellectromagnetics 24:39-48

Al-Harahsheh M, Al-Muhtaseb AH, Magee TRA (2009) Microwave drying kinetics of tomato pomace: effect of osmotic dehydration. Chem Eng Process 48(1):524-531

Aniszewska M (2004) Analiza procesu cieplnego wyłuszczania nasion z szyszek sosny zwyczajnej (Pinus sylvestris L.), praca doktorska. Wydział Leśny SGGW, Warszawa

Aniszewska M (2007) Efektywność łuszczenia szyszek sosny zwyczajnej w warunkach produkcyjnych. Sylwan 151(9):22-28

Aniszewska M (2012) Dynamika procesu pozyskania nasion w jednoi dwuetapowych procesach łuszczenia szyszek sosny zwyczajnej (Pinus sylvestris L.). Rozprawy naukowe i monografie. Wydawnictwo SGGW

Antosiewicz Z (1979) Wpływ temperatury i wilgotności powietrza na jakość nasion sosny i świerka w czasie łuszczenia szyszek. Las Polski 6:11-12

Backer LF, Walz AW (1985) Microwave oven determination of moisture content of sunflower. Trans ASABE 28(6):2063-2065

Białobok S, Baratyński A, Bugała W (1993) Biologia sosny zwyczajnej. Poznań-Kórnik: Polska Akademia Nauk Instytut Dendrologii: 624

BN-76/9211-02 (1976) Materiał siewny. Nasiona drzew i krzewów leśnych i zadrzewieniowych

Bogdanow BP (1966) O suszkie szyszek w wakuomie. Lesnoje chozjajstwo $3: 57-60$
Brusewitz GH (1984) Microwave drying for moisture determination with accuracy related to temperature. Trans ASABE 27(4):1217-1221

Contreras C, Martín-Esparza ME, Chiralt A, Martínez-Navarrete N (2008) Influence of microwave application on convective drying: effects on drying kinetics, and optical and mechanical properties of apple and strawberry. J Food Eng 88(1):55-64

Dadali G, Apar DK, Özbek B (2007) Estimation of effective moisture diffusivity of okra for microwave drying. J Dry Technol 25(9): 1445-1450

Funebo T, Ohlsson T (1998) Microwave-assisted air dehydration of apple and mushroom. J Food Eng 38(3):353-367

Hong-Hai L, Qing-Wen W, Lin Y, Tao J, Ying-Chun CAI (2005) Modification of larch wood by intensive microwave irradiation. J Forest Res 16(3):237-240

Jakubowski T (2008) Wpływ napromieniowania mikrofalowego na dynamikę wzrostu kiełków bulwy ziemniaka. Inżynieria Rolnicza 5(103):7-13

Jakubowski T (2010) Wpływ promieniowania mikrofalowego o różnych częstotliwościach na wybrane procesy życiowe roślin ziemniaka. Materiały XVII Konferencji Naukowej Postęp Naukowo-Techniczny i Organizacyjny w Rolnictwie. Zakopane 2010:19

Khraisheh MAM, Mcminn WAM, Magee TRA (2004) Quality and structural changes in starchy food during microwave and convective drying. Food Res Intern 37(5):497-503

Krajewski A (1990a) Możliwość zastosowania mikrofal do dezynsekcji iglastego drewna budowlanego. Wydawnictwo PKZ, Warszawa

Krajewski A (1990b) Zwalczanie owadów - szkodników technicznych drewna za pomocą mikrofal. Ochrona Zabytków 168(1):27-34

Krajewski A (2001) Fizyczne metody dezynsekcji drewna dóbr kultury. Rozprawy naukowe i monografie. Wydawnictwo SGGW, Warszawa

Krug E (1990) Pollenkeimung unter Einfluss elektromagnetischer Wellen und Felder. Eur J For Pathol 20(4):251-255

Kubiak M, Laurow Z (1994) Surowiec drzewny. Fundacja Rozwój SGGW, Warszawa

Malkin VK, Panina NB (1996) Prognoz gruntovoj vschozesti semjan sosny obyknovennoj Lesn. Chozjajstvo 6:38

Maskan M (2001) Drying, shrinkage and rehydration characteristics of kiwi fruits during hot air and microwave drying. J Food Eng 48(2): 177-182

Nelson SO (1985) RF and microwave energy for potential agricultural applications. J Microw Power 28:65-70

Pietruszewski S, Kania K (2011) Wpływ promieniowania mikrofalowego na kinetykękiełkowania nasion łubinu białego i grochu konsumpcyjnego. Acta Agrophys 18(1):121-129

Pinkrova J, Hubackova B, Kadlec P, Prihoda J, Bubnik Z (2003) Changes of Starch during microwave treatment of rice. Czech $\mathrm{J}$ Food Sci 21(5):176-184

PN-R-65700:1998 Materiał siewny -Nasiona drzew i krzewów leśnych i zadrzewieniowych

Pravdin LF (1964) Sosna obyknovennaja Izmencivost ‘vnutrividovaja sistematika i selecija. Jzd. „Nauka“, Moskva

Rukuni D (1997) Seed Extraction Methods and Quality Effects in Pinus radiata D. Don. Master thesis of Applied Science in Seed Technology at Massey University, Palmer North, New Zealand

Słowiński K (2013) Wpływ promieniowania mikrofalowego wyemitowanego do nieodkażonego podłoża szkółkarskiego na przeżywalność i wybrane cechy jakościowe sadzonek sosny zwyczajnej (Pinus sylvestris L.) Zeszyty naukowe Uniwersytetu Rolniczego im. Hugona Kołłątaja w Krakowie nr 517, rozprawy zeszyt 394 
Soysal Y (2004) Microwave drying characteristics of parsley. Biosyst Eng 89(2):167-173

Staszkiewicz J (1968) Badania nad sosną zwyczajną z Europy południowo-wschodniej I Kałkazu oraz jej stosunkiem do sosny z innych obszarów Europy, oparte na zmienności morfologicznej szyszek. Florist Geobot 14(3):259-315

Statistica 10 (2011) Start Soft. www.statsoft.com

Thuery J (1992) Microwaves: industrial, scientific and medical applications. Artech Houses Publishers, Norwood

Vadivambal R, Jayas DS (2007) Changes in quality of microwavetreated agricultural products-a review. Biosyst Eng 98(1):1-16
Velázquez-Martí B, Gracia-Lopez C, Maral-Domenech A (2006) Germination inhibition of undesirable seed in the soil using microwave radiation. Biosyst Eng 93(4):365-373

Warchalewski JR, Dolińska R, Błaszczak W (2007) Analiza mikroskopowa ziarna pszenicy dwu pokoleń wyhodowanych z nasion ogrzanych mikrofalami. Acta Agrophys 10(3):727-737

Załęski A (1995) Nasiennictwo leśnych drzew i krzewów iglastych. Wydawnictwo Świat, Warszawa, p 179

Zhang M, Tang J, Mujumdar AS, Wang S (2006) Trends in microwave-related drying of fruits and vegetables. Trends Food Sci Technol 17(10):524-534 